\title{
Ecosystem Services in the Nemunas Delta: Differences in Perceptions of Farmers, Birdwatchers and Scientists
}

\author{
Rasa Morkūnè $\mathbb{1}^{1}{ }^{1} \cdot$ Zita Rasuolè Gasiūnaitè $^{1}$ Jan Žukovskis ${ }^{1,2} \cdot$ Lina Marcinkevičiūtè ${ }^{1,2}$ • \\ Artūras Razinkovas-Baziukas ${ }^{1}$
}

Received: 30 April 2021 / Accepted: 9 October 2021 / Published online: 29 October 2021

(c) The Author(s), under exclusive licence to Springer Science+Business Media, LLC, part of Springer Nature 2021

\begin{abstract}
Engaging relevant stakeholders to identify ecosystem services is an important step in ensuring better management actions and nature protection. In this study, we involved three stakeholder groups that gave their opinions on different aspects regarding the usage, threats and protection of ecosystem services in the Nemunas Delta region (south-eastern Baltic Sea). Opinions from 178 respondents, representing local farmers, birdwatchers and scientists were collected in order to evaluate the importance of ecosystem services and to distinguish the most effective actions to sustain them. Despite many differences, there was a clear consensus among all three respondent groups about the importance of some ecosystem services such as water quality, water cycle, habitats for migratory animals, existence value, nature watching, subject for education and research and recreation. Birdwatchers appeared to be helpful in ecosystem services evaluation for their experience-based knowledge in this study region, but the differing perceptions of different groups on the majority of ecosystem services showed how important it is to include more than one stakeholder group in the assessment. The respondents did not agree about the actions needed to sustain ecosystem services-this highlights a need for compromises between anthropogenic activities and environmental protection, while an agreement on the necessity (willingness) to preserve natural values points to future development directions for the Nemunas Delta Region.
\end{abstract}

Keywords Questionnaire $\cdot$ Protection $\cdot$ Public engagement $\cdot$ Curonian lagoon

\section{Introduction}

The ecosystem services (ES) approach has increasingly become an important way to communicate about the benefits of nature and nature conservation. In order to evaluate multiple diverse ES, there is a need to engage with relevant stakeholders that encounter the ES through their everyday life, work, nature observations or scientific research. The selection and inclusion of stakeholders can be considered an essential task for ES evaluation when deciding on the

Supplementary information The online version contains supplementary material available at https://doi.org/10.1007/s00267021-01550-2.

Rasa Morkūnè

rasa.morkune@ku.lt

1 Marine Research Institute, Klaipeda University, Klaipeda, Lithuania

2 Vytautas Magnus University, Kaunas, Lithuania economic importance of the ES, their management strategies and conservation priorities (Hanna et al. 2018). Attention to ES assessments has increased especially in protected areas (PA) where the provision of multiple ES are related to nature protection and anthropogenic activities. It is important in general to protect these territories and they usually have ongoing monitoring activities that result in better availability of environmental data needed for various assessments, including the evaluation of ES.

Riverine ecosystems, including river deltas, are subject to seasonal hydrological cycles and increasing pressure resulting from human usage (Hanna et al. 2018) and climate change, while human activities, as well as environmental protection actions here, might be highly dependent on the hydrological patterns. Historically in the Nemunas Delta area (south-eastern Baltic Sea), engineering solutions to control water levels have allowed not only farming and living but also habitat variety and rich biodiversity (Bastienė and Šaulys 2007; Sendzikaite 2013). Previous studies on ES in the delta area have contributed to the understanding of the direct benefits of the ES to people, including 
the provision of food, fuel, transportation, climate regulation, water purification, natural hazards regulation, fishing, recreation and other cultural goods (Rashleigh et al. 2011).

As anthropogenic activities in PAs have been considered increasingly integral to the ecological research agenda and conservation, the socio-ecological system approach has become a must in environmental management (Petrosillo et al. 2015). This suggests that in seeking effective PA management, a more multidisciplinary approach to ES evaluation and a broader scope for possible decisions should be applied (Hummel et al. 2017). Decision-makers take responsibility for the effectiveness of decisions regarding further usage and the development of areas, which might (but not necessarily) come as recommendations from experts in various fields. Scientists, who often take expert roles within ES assessments, study long-term, large-scale processes and changes, usually have less interactions with other users of the area and tend to focus on the functional aspects underlying relevant ES. Scientists' perception might be different from tourists (Schernewski et al. 2019a; Urbis et al. 2019), fishermen (Armaitiene et al. 2011), private forest owners (Almeida et al. 2018), local inhabitants (Quintas-Soriano et al. 2018), PA managers (Hummel et al. 2017) and other users who deal with much shorter time frames and/or at local scales. However, the ES approach is often based on experts' (scientists') knowledge because of a lack of data and its proven relationship to the ecological and socio-economic context, especially considering regulating and maintenance ES (Carnol et al. 2014). The other respondents may not be experts, but they encounter the relevant ES in their common activities and have knowledge regarding threats to ES and opinions on priority actions that should be taken to improve or protect the ES quality or quantity (Grilli et al. 2016). Bringing the perceptions of different respondent groups together across disciplinary and professional boundaries (as scientists and practitioners in Hummel et al. 2017; Norström et al. 2020) might improve ES evaluation and protection as well as PA management. Therefore, more stakeholders, with differing areas of interest and knowledge in the various sectors, should be included in the process.

In this study, we compiled ES valuations in the Nemunas Delta region from three groups of stakeholders: farmers, birdwatchers and scientists. They all are closely related to the region of interest through their main interests, be it living or working there, observing nature or carrying out scientific research. We hypothesise that the perceptions of the respondents regarding ES and their preferences for management actions depend on their activities, experiences and direct ES use. In any ecosystem, whereas the value and threats facing ES could be overlooked if considering a single group of respondents. We demonstrate that the differences and consensus between respondent groups might be important in revealing the broader picture of ES usage, as well as their protection needs and trade-offs that occur.

\section{Materials and Methods}

\section{Description of Study Site}

This study was performed in the Nemunas Delta region on the north-eastern side of the Curonian lagoon (south-eastern Baltic Sea) (Fig. 1). The Nemunas is a lowland transboundary river with a catchment area of $92,318 \mathrm{~km}^{2}$ (fourth largest in the Baltic region (Nilsson and Langaas 2006)). Most of the area is protected against seasonal flooding by a summer polder system, with a relatively small area, including settlements and arable land, under constant protection by winter polders all year round. The polder system covers nearly $500 \mathrm{~km}^{2}$, with $300 \mathrm{~km}^{2}$ of this available for agricultural purposes. Regarding land use by local farmers, grassland and pastures dominate the polders and cover $84 \%$ of the area, while arable land accounts for $7 \%$ of the total area (Bastienè and Šaulys 2007; Dumbrauskas and Punys 2003).

Located in Šilute district, the territory of this study totals $940 \mathrm{~km}^{2}$, and includes the Nemunas Delta Regional Park (Fig. 1) with 13 NATURA2000 territories (seven of them dedicated for habitats, six for birds), one biosphere polygon,

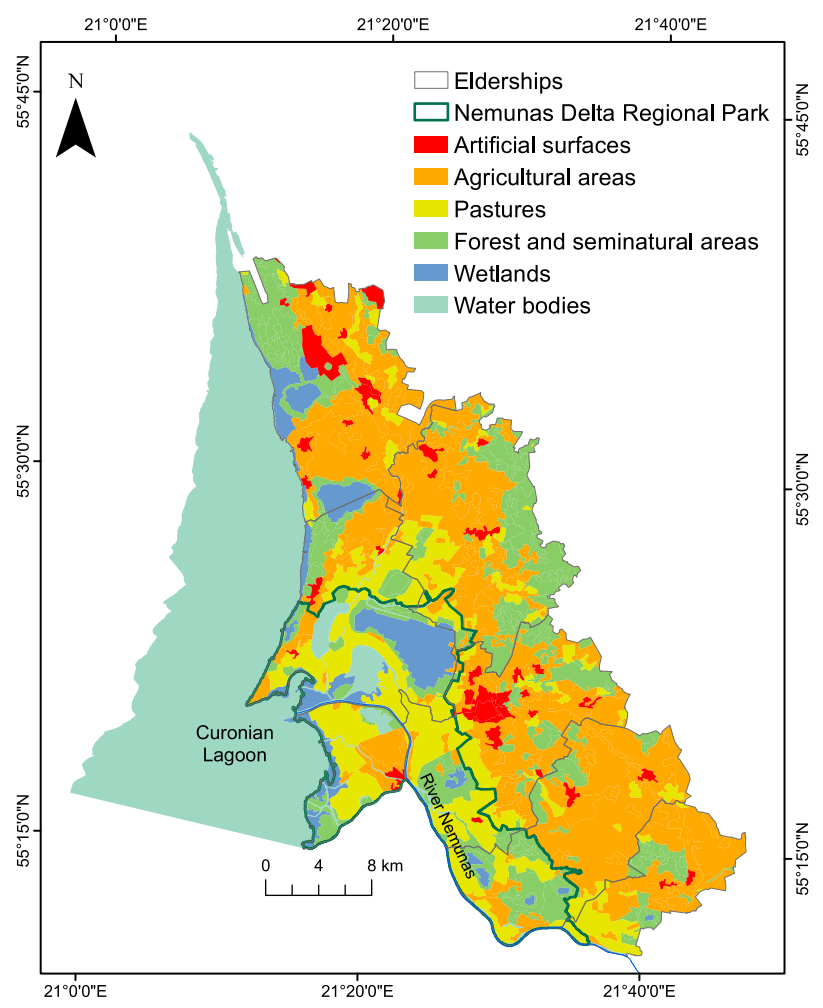

Fig. 1 Study area in the Nemunas Delta region, south-eastern Baltic Sea 
31 reserves and two strict preserves. The Nemunas Delta is considered to be one of the most important bird areas in Lithuania due to the large numbers of waterbirds that congregate at the site on passage (autumn and spring) and during the moulting season or breed in the rich and diverse assemblage of wetlands, meadows, flood-meadows, reed beds, rivers, lakes and forests (Raudonikis et al. 2000).

\section{Selection of Respondent Groups}

We included three groups of respondents in the survey: farmers, birdwatchers and scientists. Local farmers live or work inside the PA and experience both constraints and benefits arising from the protection status, as well as seasonal floods on their property or around. As farming activities are strongly affected by the seasonal floods in the Nemunas Delta, the cultivation of crops and vegetables is possible only in areas protected from the flood, while meadows, flooded in the spring, are later used as pastures and for haymaking (Bastienè and Šaulys 2007; Dumbrauskas and Punys 2003). Cattle grazing and haymaking, as well as natural processes, e.g. floods and ice drifts, prevent the area from overgrowing with reeds, shrubs and trees (Nature Management Plan for Sausgalviai Grasslands 2007). Moreover, local farmers have been involved in the application of optimal timing and technologies of mowing grasslands for Aquatic Warbler, the rarest and the only globally threatened passerine bird in Europe (Stoškus et al. 2015). As the activity of farmers impacts many ES, their responses are important in this study.

As floods and habitat diversity create good conditions for rich biodiversity, nature watching and especially birdwatching is a popular recreation activity in the area. Considering their frequent visits and long periods spent in the field, birdwatchers can be recognised as experts of the area (Karlonas 2017; Kronenberg 2014), thus, we included a number of members of the Lithuanian Ornithological Society to this survey.

The territory is also important in terms of scientific studies in fields ranging from natural science to engineering and social studies (e.g. Gozdowski et al. 2020; Valiuškevičius et al. 2018; Verkulevičiūtè-Kriukienè et al. 2018), thus we also invited a number of scientists working in the Lithuanian coastal region to take part in the survey regarding ES of the Nemunas Delta. Many other studies have involved scientists as possible stakeholders to evaluate ES at various scales and various ecosystems (e.g., Almeida et al. 2018; Hummel et al. 2017), including the Nemunas Delta (Paulauskas et al. 2011) and Lithuanian territory (Depellegrin et al. 2016). In this study, the involvement of scientists was important in order to get a general assessment on ES, especially on those that might need specific theoretical knowledge about processes in the Nemunas Delta.

\section{Data Collection and Analysis}

We used printed and interactive questionnaires to collect responses from 58 farmers, 56 birdwatchers and 64 scientists. Farmers were asked to fill in the printed questionnaires in June-August 2018 at sub-district administrations. For other groups, we conducted interactive presentations with the questionnaire-for birdwatchers at the Annual Birdwatchers Meeting (Birdlife Lithuania) in March 2019 and for the scientists' community at the national "Marine and Coastal Research 2019” conference in May 2019.

The questionnaires had three sections:

1. Social profiles of the respondents with different explanatory variables within the groups as following:

- Birdwatchers: gender, age, type of regular job, the purpose of the visits to the area;

- Farmers: proportions of land types owned, main agricultural activities, water access, relationship to the PA, restrictions and financial benefits due to the PA relationship; type of regular job was assumed to be nature related;

- Scientists: gender, age, scientific field.

2. Opinions of respondents in relation to selected ES. Respondents were asked to assess each of 29 selected ES (CICES 5.1; Haines-Young and Potschin-Young 2018) (Table 1) using a scale from 1 (not important) to

Table 1 Total list of ecosystem services by sections used for the assessment

\begin{tabular}{|c|c|c|}
\hline Provisioning services & $\begin{array}{l}\text { Regulating and } \\
\text { maintenance services }\end{array}$ & Cultural services \\
\hline Cultivated crops & Water quality & Heritage \\
\hline $\begin{array}{l}\text { Reared animals, their } \\
\text { outputs }\end{array}$ & Air quality & Aesthetic value \\
\hline Hunting & Water cycle & Religious value \\
\hline Fisheries & Pollination & Existence value \\
\hline $\begin{array}{l}\text { Wild plants } \\
\text { (mushrooms, berries) }\end{array}$ & $\begin{array}{l}\text { Habitats for migratory } \\
\text { animals }\end{array}$ & Nature watching \\
\hline Water for drinking & $\begin{array}{l}\text { Habitats for plants, } \\
\text { local animals }\end{array}$ & Leisure fishing \\
\hline Non-drinking water & Climate regulation & $\begin{array}{l}\text { Subject for education } \\
\text { and research }\end{array}$ \\
\hline Minerals & & Recreation \\
\hline \multicolumn{3}{|l|}{ Timber } \\
\hline \multicolumn{3}{|l|}{ Biofuel } \\
\hline \multicolumn{3}{|l|}{ Wind energy } \\
\hline \multicolumn{3}{|l|}{ Sun energy } \\
\hline Water energy & & \\
\hline
\end{tabular}


5 (very important). The opinions considered the importance of a particular ES according to a combination of its presence, necessity and/or existing actual threats of losing it. Each respondent evaluated the importance of all selected ES, but skipping an option was possible if a respondent did not feel competent to answer that question. The method allowed for respondents to mark everything as equally important or not important if they wish.

3. The perceptions of respondents regarding possible risk mitigation actions to preserve existing ES in the study area were assessed on a scale from 1 (least importance) to 3 (high importance).

These suggested actions were based on already existing legislative tools available in the decrees issued by the Parliament of Lithuania. The following measures with explanations were used in the questionnaires:

- Protection of habitats (especially introducing Natura2000)

- Decrease of pollution (includes both chemical and physical pollution)

- Control of physical parameters (e.g. flood control)

- Management of biological parameters (e.g. management of meadows, control of invasive species)

- Regulation of provisioning services (e.g. fishery, hunting, forestry)

- Management of agricultural activities (e.g. fertilization, pesticides, number of cattle)

- Engagement (e.g. subsidies, promotion of organic farming).

\section{Data Analysis}

The survey resulted in 178 valid responses covering the three groups of respondents. We checked whether four variables within the social profiles and preferences were important when scoring the three main ES categories using analysis of variances (Anova) and Tukey test. The tested variables were as follow:

- Group: birdwatchers, farmers, scientists;

- Regular job: nature related, technology, others;

- Gender: men, women;

- Age: classes of $20-30,30-40,40-50,50-60,60-70$, $>70$ years.

We analyzed the differences in perception of ES by the three respondent groups (birdwatchers, farmers and scientists) using the non-parametric Kruskal Wallis test and Dunn's test. The homogeneity of variances was assessed by
Levene's test. All statistical analysis was performed using R.4.0 (R Core Team 2020). In Figs. 2-4, box plots showed medians (solid line), interquartile range (IQR or a distance between the 25th an 75th percentiles) (box outline) and spread of data without outliers (whiskers) for each group. The boxplots were produced using ggplot in $\mathrm{R}$; jitter function was applied to avoid overlaps of the points.

Relationships between provided scores within a respondent group were identified using Spearman correlation. Variations of scores within and among groups were estimated by PCA applied to evaluate the overall relationship among groups and ES perceptions using the FactoMineR package (Lê et al. 2008). As some groups of respondents (particularly farmers) did not cover the whole spectrum of ES in their answers, thereby preventing some statistical calculations, we applied the missMDA package (Josse and Husson 2016) to impute missing values.

\section{Results}

\section{Social Profiles of Respondents}

Questions relating to the social profiles were different for each stakeholder group (Appendix A), but the similarity of several questions gave the possibility to check the most significant variables impacting opinions regarding the ES. Majority of the 182 respondents were males. In the groups of birdwatchers and scientists, males accounted for 57 and $52 \%$ respectively, while an overwhelming majority of farmers were also males $(>90 \%)$. Both birdwatchers and scientists were dominated by 20 to 50 -year old persons (79\% in both groups).

Most birdwatchers $(60 \%)$ indicated that they visited the area for hobby and entertainment, while $16 \%$ of them indicated work as the main reason and $15 \%$ as they live in the area. $64 \%$ of all birdwatchers indicated having naturerelated work, $13 \%$ indicated a business job profile.

Regarding the profiles of scientists, two-thirds of them worked in natural science fields, one-third in technology, while only a negligible part of the scientists represented other fields.

Local farmers mostly owned grasslands and arable lands, though some of their owned areas were located in forests, wetlands, water bodies or on the coastline of the Curonian lagoon. Up to $5 \%$ of farmers owned areas considered as coastal, while $66 \%$ of farmers indicated having access to various types of water bodies, including both the Curonian lagoon and inland bodies. The main activities of farmers were growing crops and vegetables as well rearing animals. Half of the farmers indicated that their property bordered the PA. $63 \%$ of farmers indicated that their activities were constrained by PA regulations but only $37 \%$ of them obtained financial support because of these restrictions. 

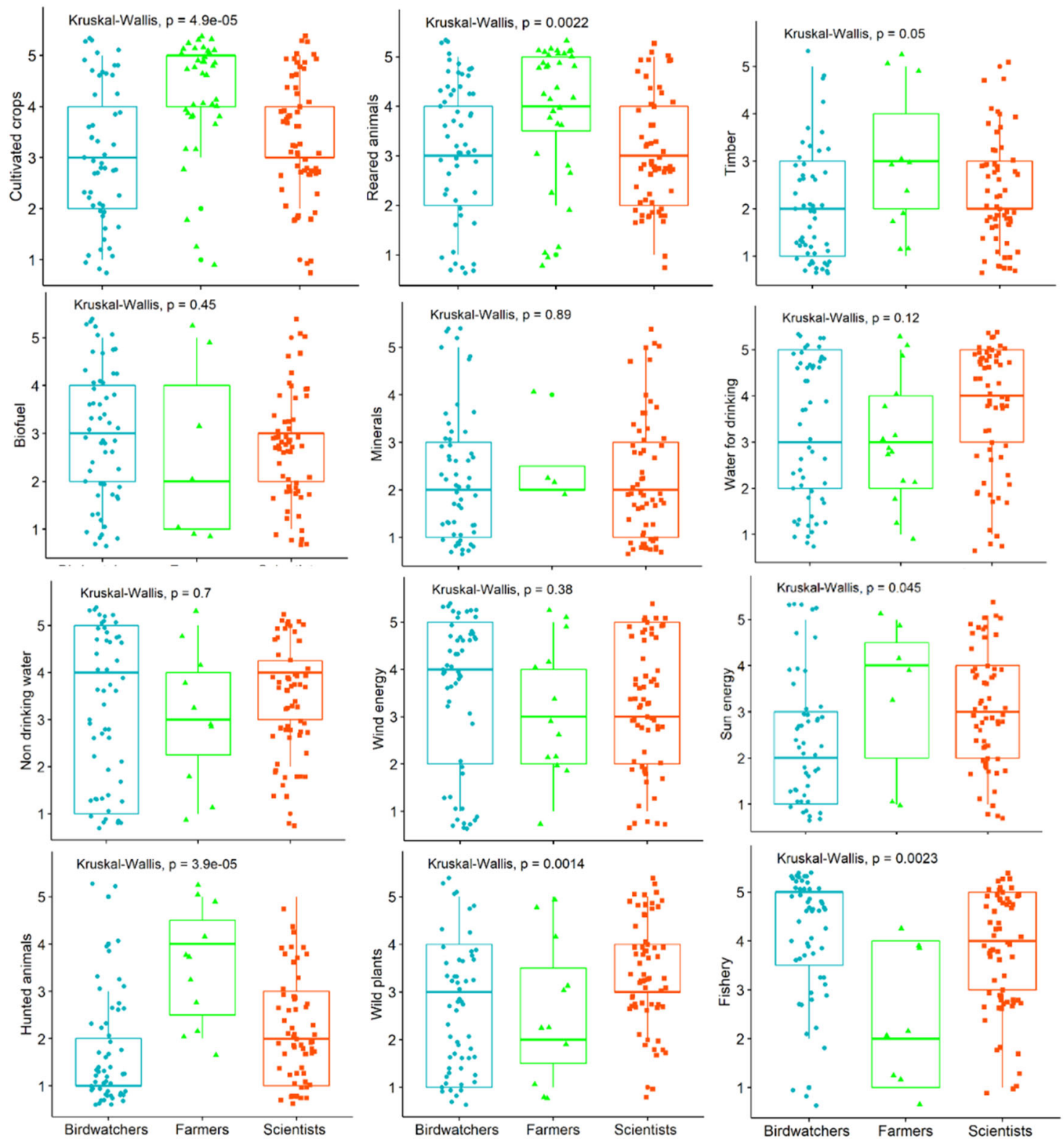

Fig. 2 Comparisons of perceptions for provisioning ecosystem services among the respondent groups

\section{Respondents' perceptions on sections and classes of ecosystem services}

The analysis of variance indicated that the three main ES categories (provisioning, regulating and maintenance, cultural) did not vary significantly according to the different classes of the social variables of the respondent groups or their occupation (regular job, scientific field) (Table 2). However, perceptions regarding regulating and maintenance of ES varied significantly among age classes (ANOVA, $F=2.806, \quad p=0.01$ ) with a discriminated difference between the age groups of 20-30 and 50-60 years (Tukey test, $p<0.05)$. In general, the highest average scores were given by 20 to 30 -year-old persons and the lowest scores came from 50 to 60-year-old group (Appendix A).

The opinions of groups were the most different within provisioning ES (Fig. 2). The benefits of cultivated crops, reared animals and their products, as well as timber, sun energy and hunted wind animals (Kruskal-Wallis, $p<0.05$ ) were scored higher by farmers than birdwatchers and scientists. Farmers judged fishery as well as wild plants of lower importance than the other two groups (Krus kal-Wallis, $p<0.05)$. Importance scores for minerals, biofuel, drinking and non-drinking water and wind energy were not different among the groups (Kruskal-Wallis, $p>0.05$ ). 
Table 2 Analysis of variances (ANOVA) of average importance scores for different sections of ecosystem services within four variables of respondents' social profiles and preferences

\begin{tabular}{llll}
\hline Variables of social profiles* & \multicolumn{2}{l}{ Sections of ecosystem services } \\
\cline { 2 - 4 } & Provisioning & Regulating and maintenance & Cultural \\
\hline Groups $^{\mathrm{a}}$ & $F=3.921, p=0.0501$ & $F=0.562, p=0.455$ & $F=0.017, p=0.898$ \\
Regular job $^{\mathrm{b}}$ & $F=2.407, p=0.0693$ & $F=1.906, p=0.131$ & $F=0.731, p=0.535$ \\
Gender $^{\mathrm{c}}$ & $F=2.834, p=0.063$ & $F=0.463, p=0.631$ & $F=1.022, p=0.363$ \\
Age $^{\mathrm{c}}$ & $F=1.211, p=0.306$ & $\boldsymbol{F}=\mathbf{2 . 8 0 6}, \boldsymbol{p}=\mathbf{0 . 0 1 4}$ & $F=0.81, p=0.564$
\end{tabular}

Numbers in bold present significant results

${ }^{a}$ Groups of birdwatchers, farmers and scientists were used for the analysis

${ }^{b}$ Regular job or fields used for the analysis of the three groups: nature related, technology and others. Farming was assumed as a nature related job

${ }^{\mathrm{c}}$ Gender and age variables were used only from the social profiles of birdwatchers and scientists, while farmers were excluded
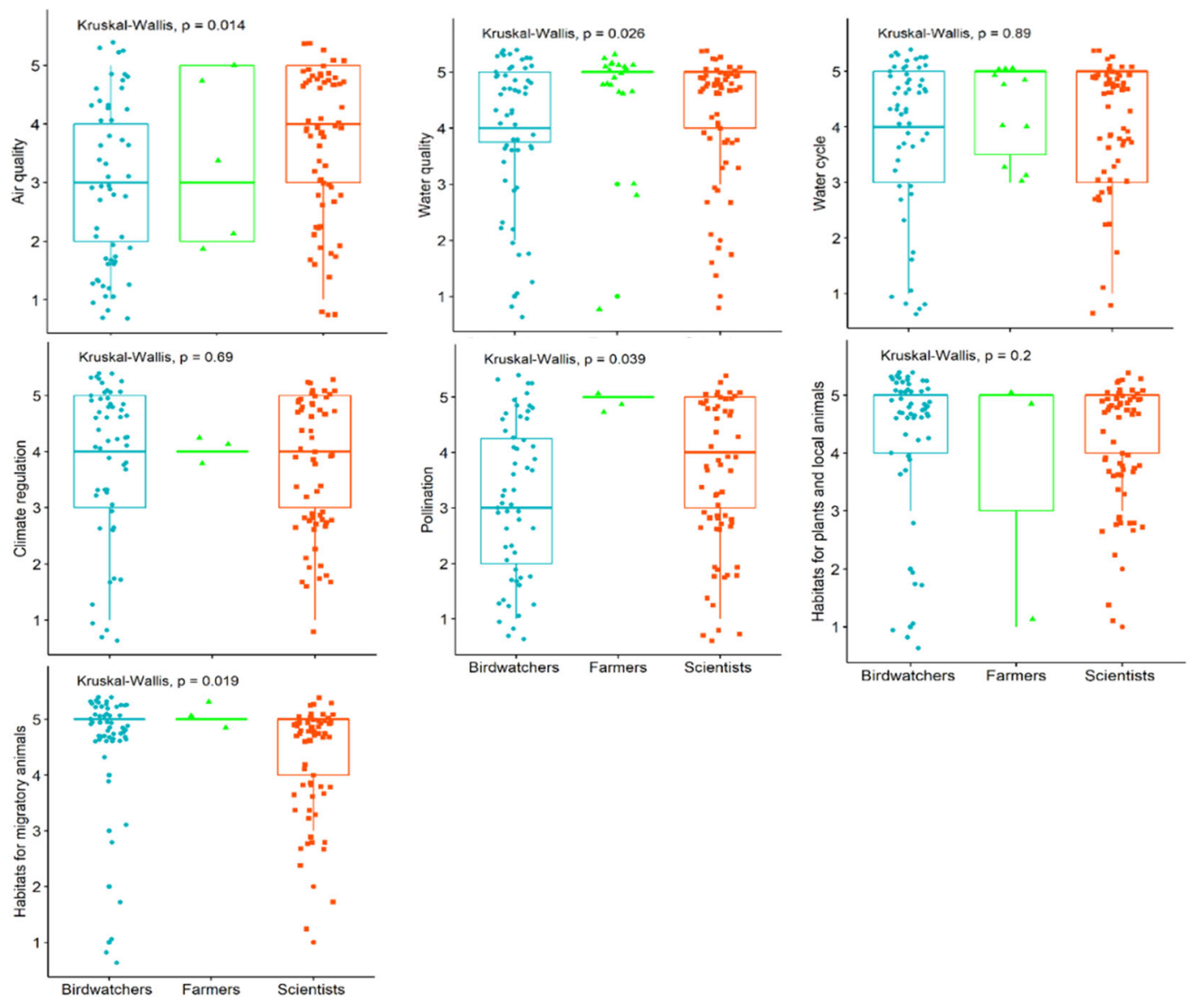

Fig. 3 Comparisons of perceptions for regulating and maintenance services among the respondent groups

Considering regulating and maintenance services (Fig. 3), farmers were the most reluctant in assigning scores for these ES and frequently left those questions blank. However, they eagerly provided scores for water quality and water cycle. Water quality was important to all groups; but the farmers' evaluation was higher than the scores given from the other two groups (Kruskal-Wallis, $p<0.05$ ). The importance of air quality and pollination was different among the groups but, despite a few high scores for pollination from farmers, the scores for these ES given by scientists were higher than ones from birdwatchers and farmers. Scientists scored habitats for migratory animals as important, while birdwatchers judged them of the highest importance (Kruskal-Wallis, $p<0.05$ ). Habitats for plants and local animals were considered to be important for birdwatchers and scientists even though their scores varied from lowest to the highest without significant differences between these groups (Kruskal-Wallis, $p>0.05$ ). 

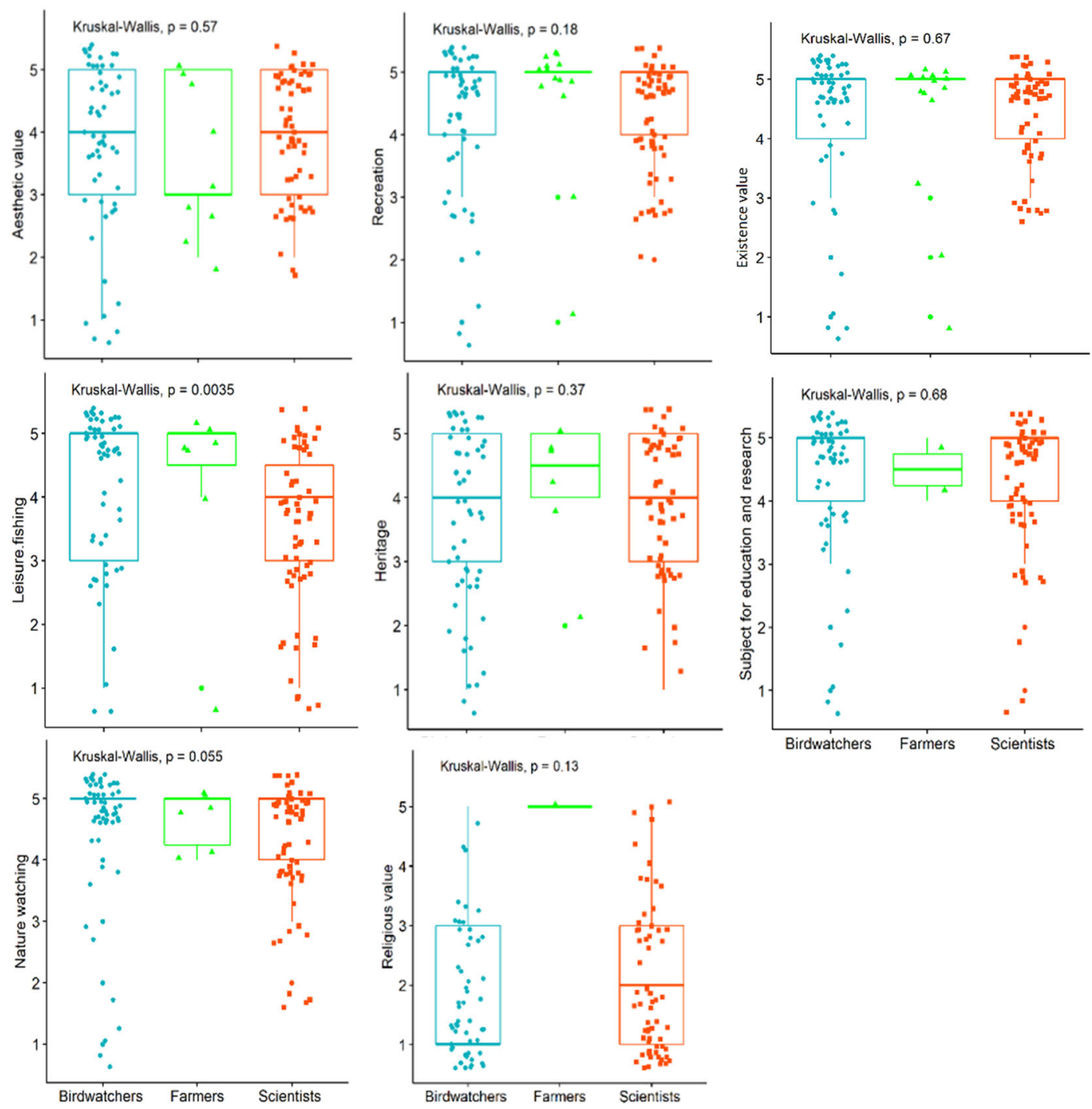

Fig. 4 Comparisons of perceptions for cultural ecosystem services among the respondent groups

Respondent groups agreed on the importance of cultural services (Kruskal-Wallis, $p>0.05$ ): a very high importance for existence value, nature watching, recreation, possibilities for education and research; high scores for aesthetic value and heritage was recorded (Fig. 4). Only the importance of recreational fishing differed between groups (Kruskal-Wallis, $\mathrm{p}<0.05$ ): majority of scientists scored it as important, but birdwatchers and farmers estimated this ES as of the highest importance. Birdwatchers and scientists judged religious value as lowest or low importance, while a negligible number of farmers scored this ES as important.

PCA analysis revealed that the responses in all ES sectors given by farmers and scientists were more similar than those of birdwatchers (Fig. 5). It was especially seen on provisioning ES, while perceptions on regulating and maintenance ES were the most different among groups. Cultural services were evaluated similarly by all groups.

\section{Relationships Between ES Evaluations Within Respondents}

Considering relationships between the ES scores provided by three groups of respondents (Figs. 6-8), correlations between individual ES scores provided by farmers were mainly significantly positive, while approximately half of the relationships coming from birdwatchers were significantly positive and only $15 \%$ of significant positive correlations were between ES scores from scientists. The negative correlations occurred between leisure fishing and water energy evaluated by birdwatchers (Fig. 6) and farmers (Fig. 7). Two negative relationships in scientists' responses were between the scores for hunting and recreation as well as leisure fishing and air quality (Fig. 8). All other correlation coefficients were statistically insignificant.

The strongest relationships in scores by the birdwatcher group (Fig. 6) were identified between cultivated 

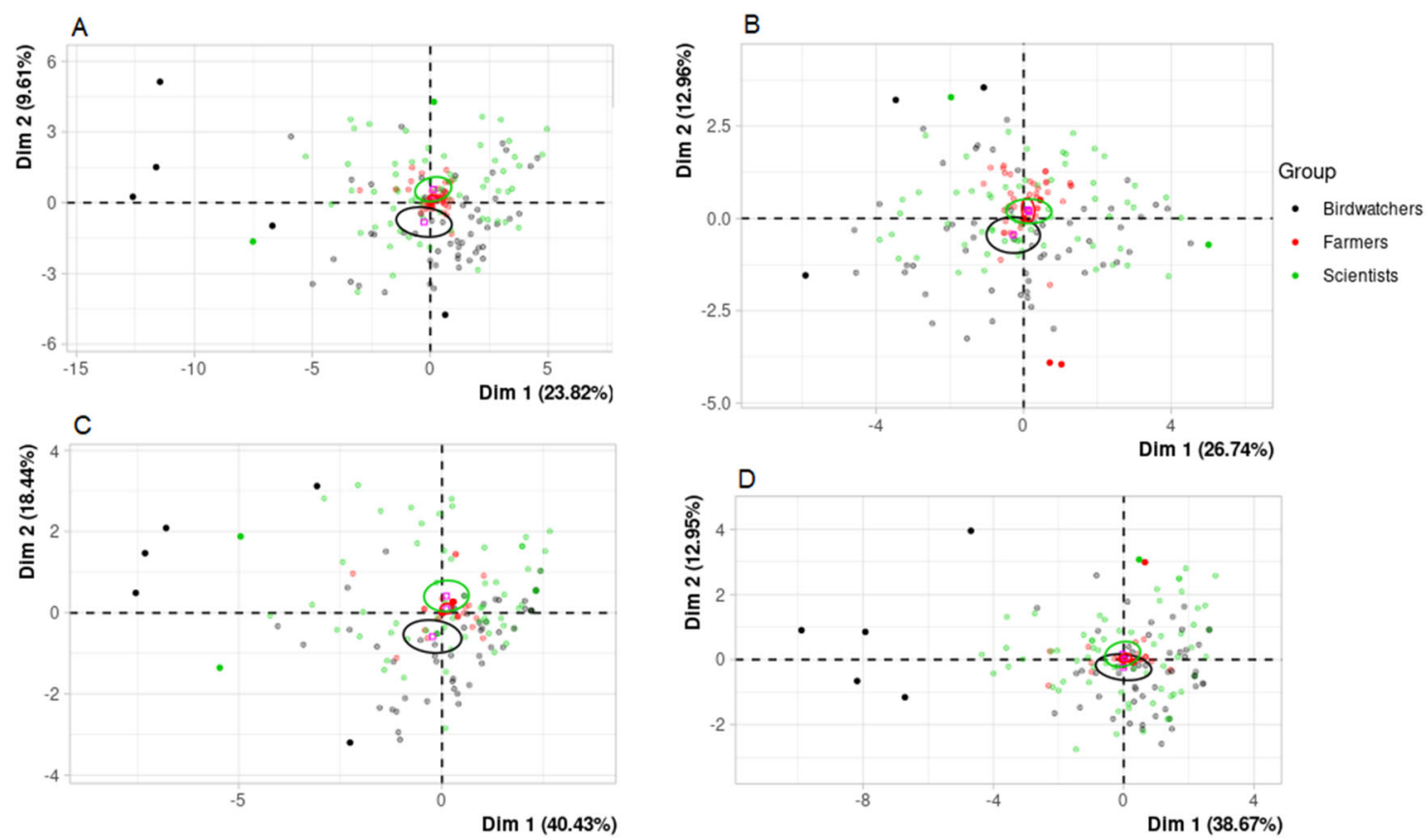

Fig. 5 Variability of perceptions within the respondent groups according to sectors of ecosystem services (PCA analysis, the first two axis). A - all ecosystem services, $\mathbf{B}$ - provisioning services, $\mathbf{C}$ - regulating and maintenance ecosystem services, $\mathbf{D}$ - cultural services

Fig. 6 Correlations between evaluation scores of ecosystem service importance by birdwatchers. Colour scale shows the direction of relationships. Size of circles marks the strength of correlation coefficient, while $\mathrm{X}$ indicates insignificant relationships

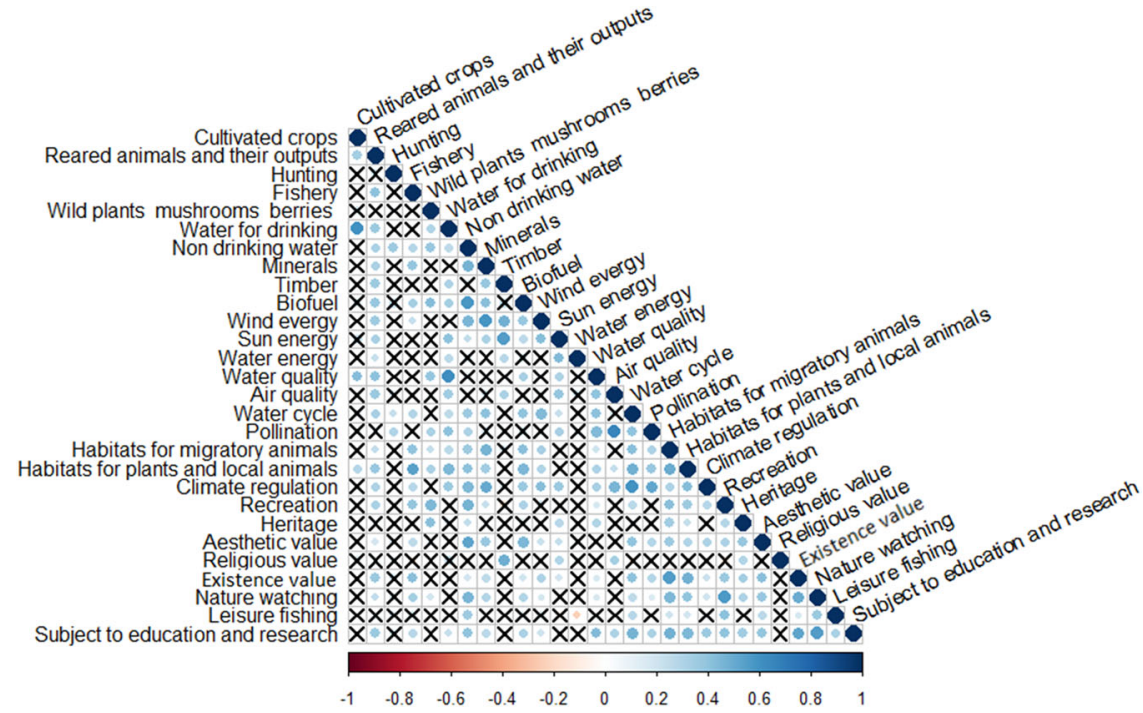

The strongest relationships among farmers (Fig. 7) were between fishery, non-drinking water, minerals, water cycle, pollination and habitats for local and migratory species. Some ES such as hunting, water energy, religious value, water quality, reared animals and their outputs and cultivated crops were less related to other ES because of a high number of non-significant relationships.

The strongest positive relationships among scientists (Fig. 8) were between the scores of wind energy, minerals and timber, as well as between the scores of pollination habitats for local and migratory species, recreation - heritage 
Fig. 7 Correlations between evaluation scores of ecosystem service importance obtained from farmers. Colour scale shows the direction of relationships. Size of circles marks the strength of correlation coefficient, while $\mathrm{X}$ indicates insignificant relationships
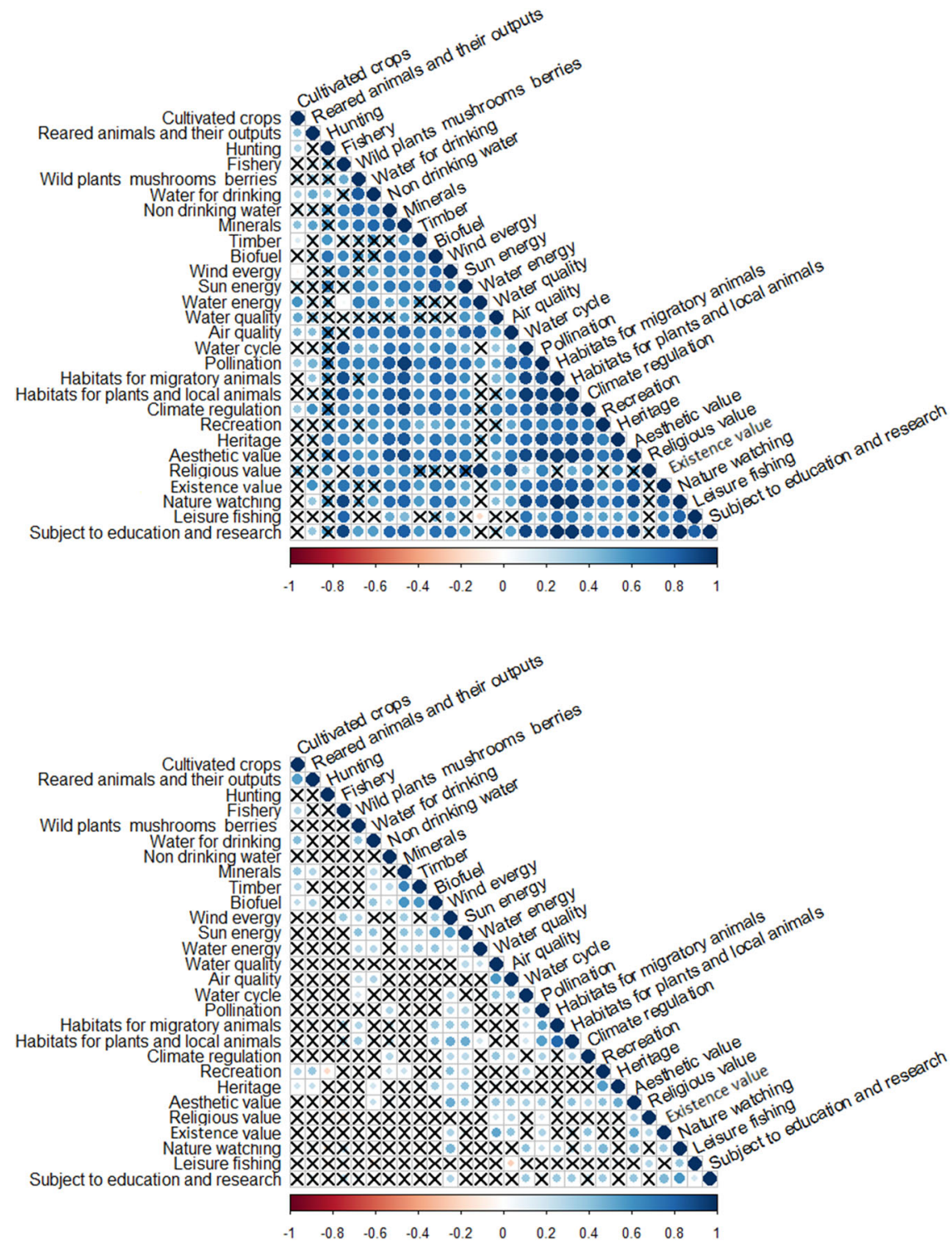

Fig. 8 Correlations between evaluation scores of ecosystem service importance by scientists. Colour scale shows the direction of relationships. Size of circles marks the strength of correlation coefficient, while $\mathrm{X}$ indicates insignificant relationships and nature watching - subject to education and research. Services as wild plants, wind energy, sun energy, water cycle, pollination and aesthetic value correlated with a higher number of services than others. The evaluation of importance scores for nature watching positively correlated to the scores of subject to education and research, leisure fishing, wind energy, water cycle, pollination, habitats for migratory species, aesthetic value and existence value.

\section{Requested Protection Actions}

Considering the protection of ES in the Nemunas Delta, the highest scores of $83-86 \%$ of birdwatchers and $76 \%$ of scientists revealed the preference for protection of habitats and management of agricultural activities, while these actions were important for a smaller percentage of farmers (52 and 36\% accordingly) (Fig. 9). Two thirds of farmers gave highest scores for control of physical parameters, while the other respondent groups did not favour this action as only $38 \%$ of birdwatchers and $23 \%$ of scientists gave the highest scores for physical parameter control. All groups indicated an average preference for a decrease of physical and chemical pollution and public engagement, including monetary incentive, and regulation of provisioning services as important actions to sustain the ES in the Nemunas Delta.

\section{Discussion}

\section{Relation of the Study Area Specifics to Stakeholders' Selection}

This study was based on the idea that the most relevant respondents for the ES evaluation might be local inhabitants 
Fig. 9 The groups' evaluations on actions to sustain present ecosystem services in the study region. The colours indicate scores - from dark as one (least importance) to light as three (high importance) given by birdwatchers (B), farmers (F) and scientists $(\mathrm{S})$

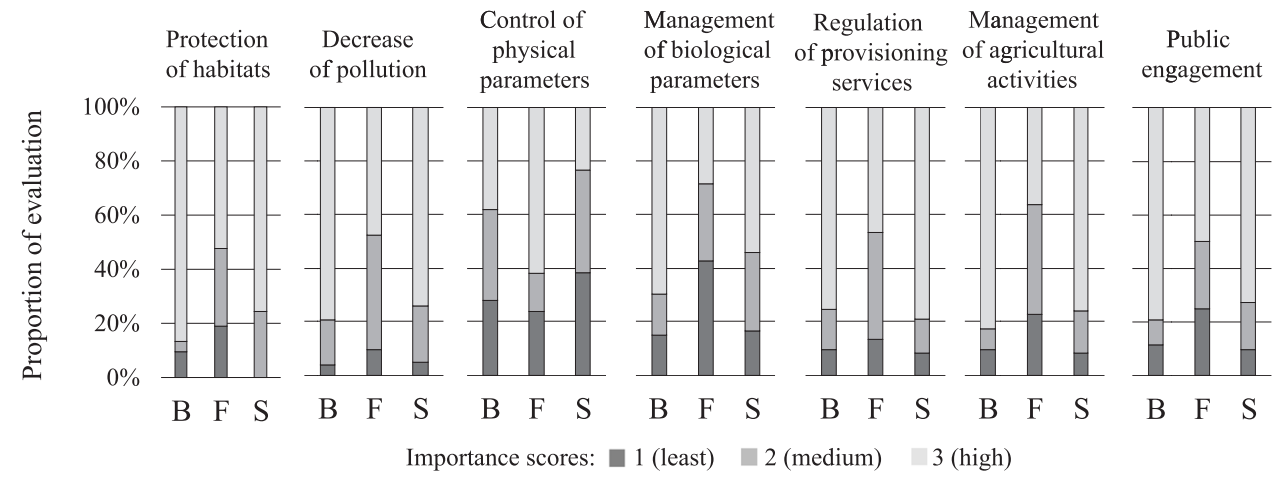

and frequent visitors, these having better experience or deeper knowledge of ES in the study area. Therefore, we have chosen local farmers, birdwatchers and scientists that either live in the Nemunas Delta region, regularly go there or have specific interests in this area. Perceptions of scientists and local farmers are quite often integrated in the ES assessments, while birdwatchers very rarely.

As birdwatchers tend to have a higher awareness of environmental problems related to habitat conservation, when compared with average respondents (Kronenberg 2014), they are important an important group for this survey in the Nemunas Delta region. The birdwatcher group mainly consisted of 20 to 50-year-old persons, which differed from other studies that had much higher average ages of respondents (e.g. average age of 67 years-old in North America (Lee et al. 2015). This age difference might result in some discrepancies of perceptions on ES, but additionally it might reflect the increasing popularity of this activity within the younger generation in Lithuania. Even birdwatching is a gender-neutral activity, traditionally men engage in it more (Lee et al. 2015). Interestingly that the gender shares were balanced in this study, although it might be related to relatively young age of Lithuanian birdwatchers. Two third of birdwatchers indicated having nature-related jobs in various parts of the country, but tended to come regularly for birdwatching in the Nemunas Delta (Appendix A). In this case, the combination of a nature-related job and birdwatching as a hobby may mean good observation skills and understanding and awareness of nature protection. In general, the data on rare bird species, phenology, migrations, breeding abundances etc. are useful for setting indicators of biodiversity and of the health of ecosystems as bird populations are responsive to environmental change and their habitats are associated with various regulating and maintenance ES. Therefore, birdwatching might contribute to collecting information on changes in bird diversity and abundances, informing revisions to subsidy systems, unsustainable practices in agriculture, fisheries and other sectors that destroy and degrade habitats (Birds and Biodiversity Targets 2020).
Precisely defined groups of stakeholders are likely to have deeper knowledge and insights in the relative assessment of ES than the public at large. In this study, the three respondent groups complement each other by reflecting a wide range of interests and knowledge of the Nemunas Delta region. All together they provided comprehensive information for this study and might be surveyed in further assessments. Of course, more social groups might be involved, though the selection of respondents should be dictated by the research question, the geographical area and the interest in specific ES. Even when respondents are mostly interested in upcoming regulations or subsidies for an activity, their opinion can be useful in selecting formats of management actions and generally filling the gap between formal scientific knowledge and the opinions of decision-makers or practitioners on ES (Almeida et al. 2018). It is important to note that the process of ES assessment should adhere to the guidelines of relevant directives, national guidelines and practical circumstances regarding the characteristics and main activities in the area.

\section{Differences in Valuation of ES Between Respondent Groups}

Scores of ES importance varied between respondent groups. In view of prior studies, we expected that society would traditionally consider the importance of provisioning ES at the expense of quality of regulating and cultural services because their value is more quantifiable, has financial importance and fits societal measures (Rodríguez et al. 2006). However, this study only partly conformed to this concept as the respondents, though giving high importance scores to several provisioning services, also prioritised habitat provisioning from the regulating and maintenance services and the majority of the cultural services. In the study of Quintas-Soriano et al. (2018), citizens appreciated provisioning services, but at the same time were highly engaged with the capacity of surrounding ecosystems to provide cultural ES. In this study, local farmers gave high 
scores to provisioning ES as cultivated crops, reared animals and their products and hunting for food. They also highlighted the importance of water quality, water cycle and pollination, these were assessed higher than by birdwatchers and scientists. This can be understood as the farmers' activities are directly impacted by these ES and their quantity or quality. Preferences of birdwatchers supported the assumption that this group has a good knowledge of the Nemunas Delta region and can give proper evaluations on natural parameters, including ecological functions and ES. They mostly assigned medium importance scores for the majority of selected provisioning ES, while the highest of them was given to fishery, non-drinking water and wind energy. Regarding the regulating and maintenance services, birdwatchers considered water quality and habitat conservation as of highest importance in the studied PA. It was shown that both social background and local ecological features play roles in influencing respondent perceptions of which ES are important (Almeida et al. 2018; QuintasSoriano et al. 2018). As we aimed to assess multiple diverse ES (Hanna et al. 2018), the chosen respondent groups fitted well for the ES assessment.

The fact that all groups, including local farmers, acknowledged the importance of habitats for local and migratory species, supported nature watching and other cultural services as well as conservation activities, might be explained by the protection status of the region. As the Nemunas Delta Regional Park was established to preserve, manage and rationally use the landscape, ecosystem and cultural heritage values of Nemunas Delta (Resolution on the Establishment of Regional Parks and Reserves 1992) and is known as an important area for migratory waterbirds, we conclude that this information is well known by society and the awareness for environmental quality and biodiversity is high. Therefore, we suppose that cultural ES are easily understood by respondents regardless of their professional or academic background in a similar way to other studies (Almeida et al. 2018). Usually, there is no specific background needed and opinions on these ES can be based on own direct and indirect experiences (e.g. through media) and general aesthetic preferences.

Some ES, including all provisioning ones, require specific knowledge in order to build an opinion (Almeida et al. 2018). Hummel et al. (2017) compared the perceptions of local natural scientists and PA managers on management strategies within a broad range of European PAs and concluded that scientists emphasised abiotic and biotic variables, while practitioners highlighted socio-economic, cultural and anthropogenic variables. Thus, people who did not encounter relevant experience can be less likely to be able to provide adequate ES importance estimates. It is for this reason that a large and diverse respondent group or different groups should be involved in ES evaluation process (Hanna et al. 2018) and both academic and nonacademic experience should be incorporated (Norström et al. 2020). This study proved that stakeholders gave higher importance scores to ES directly related to their activities or interests in the study region. However, it may be the opposite: respondents may be familiar with popular activities but not associate them with relevant ES. For example, local farmers gave low importance scores to fishing for food (provisioning ES) and leisure fishing (cultural ES) which are popular activities in the area especially for visitors (Rashleigh et al. 2011).

Our findings provide information on the most important ES and their relationships within groups while the complexity of the relationships among multiple ES might not be fully understood. In this case, the importance scores of ES had either positive or negative correlations between each other. Moreover, scores presenting higher importance could highlight an abundant or scarce but highly used or desired resource or benefit of the ecosystem function to the respondents or society in general. On the other hand, very low or very high scores of some ES could correspond to subjectively anticipated threats to other ES or living conditions, including economic benefits to respondents. An example of the difference in scoring between different groups of respondents might be the evaluation of wind energy as an ES in this study. Birdwatchers could evaluate it as a threat to biodiversity, while farmers see it as an economic benefit. However, scientists might be interested in various fields of usage and, depending on the personal scientific field, might not be aware of the impacts on biodiversity or land rental prices. Thus, even we cannot identify the particular interests of respondents, though we can discriminate the ES which causes the highest concern and use them for further investigation.

Analysis of relationships helps to recognise the complexity of ES (Lee and Lautenbach 2016). The prevalence of positive correlations among ES reveals synergies and show that proper management might sustain the quality and/ or quantity of related ES. Considering matches of all respondent groups, our study suggests that good water and air quality and suitable habitats for migratory species might promote the supply of multiple ES, while management actions should also be focused on them. Only a few negative relationships were identified, these being between leisure fishing and water energy, leisure fishing and air quality and hunting and recreation. They highlighted fishing and hunting as threats, but did not provide accurate information about trade-offs in the region. Moreover, as the Nemunas Delta Region has experienced multifunctional usage of environmental elements and human-dominated landscapes, the management should be focused to mitigate trade-offs and ensure suitable co-existence between ecosystem functions and human activities. 


\section{Actions to Sustain Future ES}

The ES approach might offer a promising way to align conservation and production, simultaneously sustaining human well-being under the regulation of provisioning services, developing cultural services and protecting regulation and maintenance services (Guo et al. 2010; Verkulevičiūtè-Kriukienè et al. 2018). Due to the designation as a PA, there are many restrictions on activities in the Nemunas Delta Regional Park: it is not allowed to perform any construction, regulation or engineering works that change land relief forms, the cultural landscape or protected complexes. Therefore, this survey did not include questions relevant to these restrictions, but it was based on different regulating actions and public engagement possibilities. Considering the actions expected to sustain ES in the Nemunas Delta, birdwatchers and scientists were mostly aware of habitat conservation and current pollution. Farmers preferred the control of physical parameters, mostly including regulation of water level as the area is flooded every year. All respondent groups selected public engagement and regulation of provisioning services as of primary importance for ES maintenance. The types of highlighted actions to sustain existing ES mostly might depend on area characteristics and users' activities in the region and might reflect public awareness of nature conservation and ES. Our results pointed out that stakeholders have diverse perspectives on the importance of ES, these based on their interest in specific ES to provide income, sustain their living environment or provide entertainment or scientific interests. Consequently, the formulation and implementation of management plans on the basis of stakeholders' interest at one institutional scale is bound to lead to sub-optimal management from the perspective of stakeholders at other scales (Hein et al. 2006). Moreover, there is a need for communication across disciplinary and professional knowledge to implement or improve ES oriented management strategies in current and especially in future PAs (Hummel et al. 2017, Norström et al. 2020). Different perceptions of stakeholders in this study increased the understanding that there is no consensus among birdwatchers, farmers and scientists on actions needed to sustain ES and highlights needed compromises among anthropogenic activities and environmental protection in the Nemunas Delta Region.

Due to the unique environmental and anthropogenic landscape, recreational activities have a future potential in the Nemunas Delta. The development of the recreational sector might improve the well-being of inhabitants and become a threat to environmental values (Belsoy et al. 2012; Verkulevičiūtè-Kriukienè et al. 2018). Differently to the neighbouring areas on the Curonian Spit or the
Lithuanian Baltic Sea coastal areas that are dominated by seasonal holiday-makers (Schernewski et al. 2019b), tourism in the Nemunas Delta is based on heritage, interactions between the hydrological regime-nature-human, and nature watching (Atkocevičienė et al. 2016; Rashleigh et al. 2011). Moreover, nature watching tourism might increase even more after the sharp decline in the overall tourism sector due to the Covid-19 situation. The pandemic encouraged interest in safe natural areas, such as can be found in PAs and in this case in the Nemunas Delta region. It is likely this will continue amid and in the post-COVID-19 situation and it is a chance for PA tourism to "built back better" than before COVID-19 by not returning to business as usual (Spenceley et al. 2021), but taking into account climate change and biodiversity, and using sustainable development principles.

\section{Conclusions}

Despite many differences, there is a clear consensus about the importance of some ES between all three respondent groups. Water quality, water cycle and habitats for migratory animals were considered to be the most important regulating and maintenance ES. This selection perfectly fits the unique characteristics of the Nemunas Delta region as a seasonally flooded area which is important for migratory birds. All respondent groups also highlighted the importance of such cultural ES as existence value, nature watching, subject for education and research and recreation. Different perceptions of the respondent groups on the majority of ES in this study showed how important it is to include more than one stakeholder group. Moreover, all groups of respondents agreed on the necessity (willingness) to preserve the mentioned natural values and pointed out the future development directions for this region. This study could be further exploited to develop future strategies for a unique delta socio-ecological system dominated by protected territories.

Acknowledgements The authors thank to Jūratė Lesutienè, Jolanta Vilkevičiūtè and Karolina Kaziukonytė for their help in preparation of the questionnaires and graphic material for the manuscript. The anonymous reviewers helped to improve the manuscript.

Author contributions: Conceptualisation, R.M.; methodology, R.M., L.M., J.Ž.; software, R.M. and A.R.B.; data curation, R.M., L.M., A.R. B..; writing —original draft preparation, R.M. and Z.R.G.; writing-R. M., Z.R.G and A.R.B.; visualisation, R.M. and A.R.B. All authors have read and agreed to the published version of the manuscript."

Funding This study has received funding from European Social Fund (project No 09.3.3-LMTK-712-01-0178) under grant agreement with the Research Council of Lithuania (LMTLT). 


\section{Compliance with ethical standards}

Conflict of interest The authors declare no conflict of interest. The funders had no role in the design, results, interpretation of the study and writing of the manuscript.

Publisher's note Springer Nature remains neutral with regard to jurisdictional claims in published maps and institutional affiliations.

\section{References}

Almeida I, Rösch C, Saha S (2018) Comparison of ecosystem services from mixed and monospecific forests in southwest germany: a survey on public perception. Forests 9(10):627. https://doi.org/10. 3390/f9100627

Atkocevičienė V, Valčiukienė J, Juknelienė D, Agintaitè-Kirstukienė K (2016) Analysis of the 20th century villages in Nemunas delta regional park. Balt Surveying: Int Sci J 2:15-22

Armaitiene A, Jones E, Povilanskas R (2011) Approaches towards the development of sustainable recreational fishing: a case study from the Nemunas Delta, Lithuania. https://repository.cardiffmet.ac.uk/ handle/10369/2707

Bastienė N, Šaulys V (2007) Analysis and evaluation of maintenance expenses of polder systems in Nemunas lowland during the last decade. Vandens Ūkio žinerija 31(51):102-110

Belsoy J, Korir J, Yego J (2012) Environmental Impacts of Tourism in Protected Areas 2(10). www.iiste.org

Birds and biodiversity targets: what do birds tell us about progress to the Aichi Targets and requirements for the post-2020 biodiversity framework. (2020). https://www.birdlife.org/sites/default/files/a ttachments/birds_and_biodiversity_targets_report.pdf

Carnol M, Baeten L, Branquart E, Grégoire JC, Heughebaert A, Muys B, Ponette Q, Verheyen K (2014) Ecosystem services of mixed species forest stands and monocultures: Comparing practitioners and scientists perceptions with formal scientific knowledge. Forestry 87(5):639-653. https://doi.org/10.1093/forestry/cpu024

Depellegrin D, Pereira P, Misiunė I, Egarter-Vigl L (2016) Mapping ecosystem services potential in Lithuania. Int J Sustain Dev World Ecol 23(5):441-455. https://doi.org/10.1080/13504509.2016.1146176

Dumbrauskas A, Punys P (2003) Character of floods of the Nemunas River Delta. International Conference "Towards Natural Flood Reduction Strategies, September, 1-7. https://www.researchgate. net/publication/237712427

Gozdowski D, Žukovskis J, Kaziukonytė K, Razinkovas-Baziukas A (2020) Evaluation of land cover changes in southwestern lithuania from 1984 to 2018 using medium spatial resolution satellite imagery. Pol J Environ Stud 29(6):4041-4051. https://doi.org/10. $15244 /$ pjoes/118745

Grilli G, Jonkisz J, Ciolli M, Lesinski J (2016) Mixed forests and ecosystem services: investigating stakeholders' perceptions in a case study in the Polish Carpathians. For Policy Econ 66:11-17. https://doi.org/10.1016/j.forpol.2016.02.003

Guo Z, Zhang L, Li Y (2010) Increased dependence of humans on ecosystem services and biodiversity. increased dependence of humans on ecosystem services and biodiversity. PLoS ONE 5 (10):13113. https://doi.org/10.1371/journal.pone.0013113

Haines-Young R, Potschin-Young MB (2018) Revision of the Common International Classification for Ecosystem Services (CICES V5.1): A Policy Brief. One Ecosystem, e27108. https://doi.org/ 10.3897/oneeco.3.e27108

Hanna DE, Tomscha SA, Ouellet Dallaire C, Bennett EM (2018) A review of riverine ecosystem service quantification: Research gaps and recommendations. J Appl Ecol 55(3):1299-1311. https://doi.org/10.1111/1365-2664.13045
Hein L, van Koppen K, de Groot RS, van Ierland EC (2006) Spatial scales, stakeholders and the valuation of ecosystem services. Ecol Econ 57(2):209-228. https://doi.org/10.1016/j.ecolecon.2005.04.005

Hummel C, Provenzale A, Van Der Meer J, Wijnhoven S, Nolte A, Poursanidis D, Janss G, Jurek M, Andresen M, Poulin B, Kobler J, Beierkuhnlein C, Honrado J, Razinkovas A, Stritih A, Bargmann T, Ziemba A, Bonet-García F, Adamescu MC, Hummel H (2017) Ecosystem services in European protected areas: ambiguity in the views of scientists and managers? PLoS ONE 12 (11):1-14. https://doi.org/10.1371/journal.pone.0187143

Josse J, Husson F (2016) missMDA: a package for handling missing values in multivariate data analysis. J of Stat Softw 70(1). https:// doi.org/10.18637/jss.v070.i01

Karlonas M (2017) Birding in Lithuania: Nemunas Delta Region. https://vivagrass.eu/wp-content/uploads/2017/12/birding-in-lithua nia-nemunas-delta-2018.pdf

Kronenberg J (2014) Environmental impacts of the use of ecosystem services: case study of birdwatching. Environ Manag 54(3):617-630

Lê S, Josse J, Rennes A, Husson F (2008) FactoMineR: An R Package for Multivariate Analysis. In JSS Journal of Statistical Software (Vol. 25). http://www.jstatsoft.org/

Lee H, Lautenbach S (2016) A quantitative review of relationships between ecosystem services. In Ecological Indicators (Vol. 66, pp. 340-351). Elsevier B.V. https://doi.org/10.1016/j.ecolind. 2016.02.004

Lee S, Mcmahan K, Scott D (2015) The gendered nature of serious birdwatching. Hum Dimens Wildl 20(1):47-64. https://doi.org/ 10.1080/10871209.2015.956375

Nature management plan for Sausgalviai grasslands (2007)

Nilsson S, Langaas S (2006) International river basin management under the EU water framework directive: an assessment of cooperation and water quality in the baltic sea drainage basin. AMBIO: A J Hum Environ 35(6):304-311. https://doi.org/10. 1579/06-A-128R.1

Norström AV, Cvitanovic C, Löf MF et al. (2020) Principles for knowledge co-production in sustainability research. Nat Sustain 3:182-190. https://doi.org/10.1038/s41893-019-0448-2

Paulauskas S, Suzdalev S, Blažauskas N (2011) Socio-economic impact assessment of the established protected areas in Lithuania. The Baltic Green Belt project. Report. 23 p. http://citeseerx.ist. psu.edu/viewdoc/download?doi=10.1.1.734.643\&rep= rep1\&type $=$ pdf

Petrosillo I, Aretano R, Zurlini G (2015) Socioecological systems. In Encyclopedia of Ecology (Vol. 4, 419-425). Elsevier. https://doi. org/10.1016/B978-0-12-409548-9.09518-X

Quintas-Soriano C, Brandt JS, Running K, Baxter CV, Gibson DM, Narducci J, Castro AJ (2018) Social-ecological systems influence ecosystem service perception: A programme on ecosystem change and society (PECS) analysis. Ecology and Society, 23(3). https://doi.org/10.5751/ES-10226-230303

Rashleigh B, Razinkovas A, Pilkaitytė R (2011) Ecosystem services assessment of the Nemunas River delta. Transitional Waters Bull 5(2):75-84. https://doi.org/10.1285/i1825229Xv5n2p75

Raudonikis L, Kurlavičius P, Matiukas G (2000) Important Bird Areas in Europe - Lithuania. http://datazone.birdlife.org/userfiles/file/ IBAs/EuCntryPDFs/IBA2000Vol1pp445-458_LT.pdf

Resolution on the establishment of regional parks and reserves. (1992)

Rodríguez JP, Beard Jr TD, Bennett EM, Cumming GS, Cork ST, Agard J, Dobson AP, Peterson GD (2006) Trade-offs across space, time, and ecosystem services. Ecol Soc 11(1):28, http://www.ecologyandsociety.org/vol11/iss1/art28/

Schernewski G, Baltranaitė E, Kataržytė M, Balčiūnas A, Čerkasova N, Méžinė J (2019a) Establishing new bathing sites at the Curonian Lagoon coast: an ecological-social-economic assessment. J Coast Conserv 23(5):899-911. https://doi.org/10.1007/s11852-017-0587-4 
Schernewski G, Baltranaitė E, Kataržytė M, Balčiūnas A, Čerkasova N, Méžinė J (2019b) Establishing new bathing sites at the Curonian Lagoon coast: an ecological-social-economic assessment. J Coast Conserv 23(5):899-911. https://doi.org/10.1007/s11852-017-0587-4

Sendzikaite J (2013) Nemunas delta. Nature Conservation Perspective. https://meldine.lt/wp-content/uploads/sites/2/2018/ 07/Nemuno_delta_EN_web.pdf

Spenceley A, McCool S, Newsome D, Báez A, Barborak JR, Blye CJ, Bricker K, Cahyadi HS, Corrigan K, Halpenny E, Hvenegaard G, King DM, Leung YF, Mandić A, Naidoo R, Rüede D, Sano J, Sarhan M, Santamaria V, Zschiegner AK (2021) Tourism in protected and conserved areas amid the covid-19 pandemic. Parks 27(Special Issue):103-118. https://doi.org/10.2305/IUCN.CH. 2021.PARKS-27-SIAS.en

Stoškus L, Sendžikaitė J, Balčiūnas V, Norvaišaitė R, Morkvẻnas Ž (2015) Protecting Aquatic Warbler: Farming in wet meadows and fen mires. https://meldine.lt/wp-content/uploads/sites/2/2018/07/ protecting-aquatic-warbler-farming-in-wet-meadows-and-fenmires-download.pdf

Team RC (2020) R: A language and environment for statistical computin. https://www.r-project.org

Urbis A, Povilanskas R, Šimanauskienè R, Taminskas J (2019) Key aesthetic appeal concepts of coastal dunes and forests on the example of the Curonian Spit (Lithuania). Water 11(6):1193. https://doi.org/10.3390/w11061193

Valiuškevičius G, Stonevičius E, Stankūnavičius G (2018) Severe floods in Nemunas River Delta. BALTICA 31(2):89-99. https:// doi.org/10.5200/baltica.2018.31.09

Verkulevičiūtė-Kriukienė D, Bučienė A, Beteika L (2018) Rural landscape status, functions and human factors in the transboundary Nemunas delta region. Area 50(3):353-363. https://doi. org/10.1111/area.12383 